\title{
Cervical cancer: Renal complications and survival after percutaneous nephrostomy
}

\author{
Alzira Carvalho Paula de Souza ${ }^{1}$, Alfredo Nunes Souza², Rubens Kirsztajn², Gianna Mastroianni Kirsztajn* \\ ${ }^{1} \mathrm{MD}$, MSc, Department of Medicine of the Universidade Federal de São Paulo (Unifesp), São Paulo, SP, Brazil \\ ${ }^{2} \mathrm{MD}$, Department of Medicine of Unifesp, São Paulo, SP, Brazil \\ ${ }^{3} \mathrm{MD}$, PhD, Department of Medicine of Unifesp, São Paulo, SP, Brazil
}

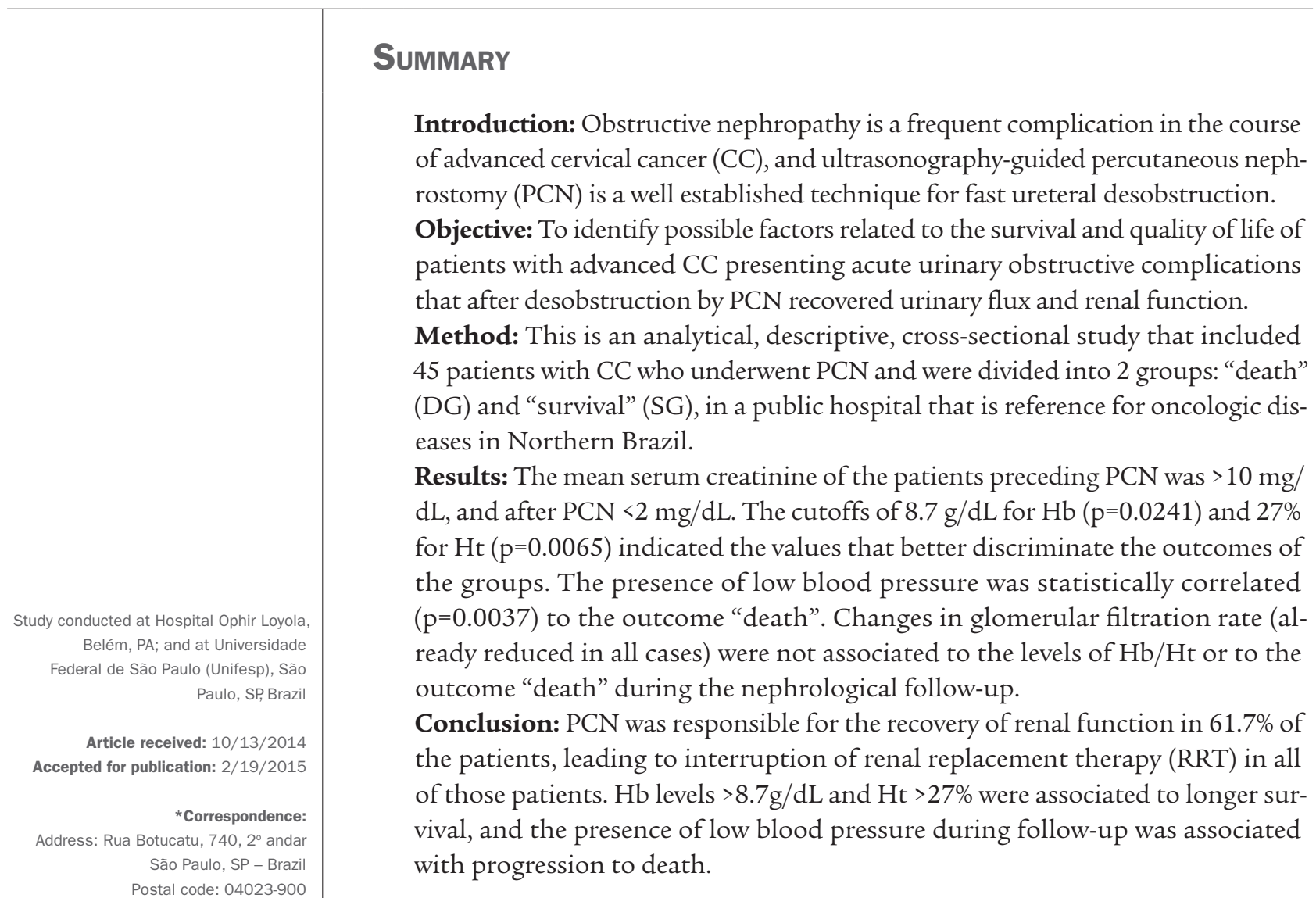

Keywords: ureteral obstruction, chronic kidney injury, percutaneous nephrostomy, anemia, creatinine, survival.

\section{INTRODUCTION}

Cervical cancer (CC) is one of the most common cancers in women, especially in developing countries, constituting a real public health problem. ${ }^{1}$

Prevention of CC is potentially effective, as there are various forms of intervention and combating the multiple manifestations of the disease. However, despite the effectiveness of control programs in many centers, CC remains a disease with high prevalence, incidence and mortality. ${ }^{2}$

Despite advancements in the treatment of urogenital neoplasms, surgical techniques, radiotherapy and chemotherapy, we still observe the frequent progression to obstructive urinary complications due to local expansion or pelvic metastases, ${ }^{3}$ which characterizes $\mathrm{CC}$ as the main pelvic tumor progressing with urinary obstruction. ${ }^{4}$

The development of obstructive acute renal failure (ARF) in patients with a malignant neoplasm results in an ethical dilemma, as renal clearance may often only be accomplished through invasive palliative procedures such as percutaneous nephrostomy (PCN), which in some cases may compromise quality of life. ${ }^{5}$

Note that in advanced stages of neoplastic disease treatment is always challenging, and thus interventions should prioritize the patient's quality of life, pain relief, assurance of hygiene and psychological care..$^{6,7}$ 
Considering the high mortality found among patients with advanced CC, particularly if complicated by obstructive ARF, studies are needed to evaluate the factors that may influence the survival and quality of life of such patients. The identification of such factors after renal clearance was the main goal of the present study.

\section{Method}

This is a descriptive, analytical cross-sectional study involving patients with advanced CC. The study was conducted at Hospital Ophir Loyola (HOL), which is a reference center in care and tertiary level treatment of cancer cases in the Northern part of Brazil. The project was submitted to the Ethics and Research Committee at the Universidade Federal de São Paulo, and approved.

Initially, the medical records of 963 patients admitted to the hospital due to a diagnosis of ARF were assessed by the Nephrology Team. The analysis period lasted from January 2010 to June 2012. We selected ninety-nine medical records of patients with CC who were submitted to PCN after being diagnosed with stage 3 (dialytic) $\mathrm{ARF}^{8}$ according to the AKIN-KDIGO classification. Sixty-one of them were discharged with improvement; 16 remained on dialysis or died; and the 45 remaining patients returned for monitoring, constituting the study group presented here (Figure 1).

We analyzed the 45 selected patients at two different times: at admission (diagnostic and therapeutic interventions including the outcomes), and in the outpatient clinic (therapeutic and diagnostic interventions, monitoring and complications). The inclusion criteria used were: female gender, being admitted to the hospital (HOL) with a diagnosis of CC (stages IIIB and IV), being over the age of 18 years, having a clinical, radiological and laboratory diagnosis of bilateral ureteral urinary obstruction, having been submitted to renal replacement therapy (RRT), and having presented recovery of kidney function after PCN.

It is worth mentioning that after $\mathrm{PCN}$ all 45 patients recovered renal function and were discharged from the hospital and referred to outpatient monitoring with the Urology and Nephrology teams.

We excluded those patients who did not recover kidney function and continued on RRT, those that progressed to death before discharge, and those presenting urinary obstruction due to gynecologic etiologies other than CC.

The 45 patients who participated in the study were divided into two groups: DG (deceased group - formed by patients who had died by the time the data was collected) and SG (survival group - patients who were still under outpatient monitoring).
The assessment of the ARF symptoms was limited to analyzing the recovery of renal function through: restoration of urinary flow and a decrease in serum levels of urea and creatinine by at least $50 \%$ of its value upon diagnosis of ARF.

The stages of chronic kidney disease (CKD) were based on the estimated glomerular filtration rate (GFR) by the equation of the "Modification of Diet in Renal Disease" (MDRD). ${ }^{9}$

Treatment evaluation and tumor staging were based on medical notes and complementary examinations (the International Federation of Gynecology and Obstetrics staging criteria). ${ }^{10}$

In the evaluation of in-hospital mortality as well as after discharge the simple frequency of death was used.

After discharge, the results of laboratory tests at two times during outpatient monitoring were compared: 1) first sample relating to the initial evaluation by the teams after discharge, and 2) final sample for the last visit noted in the medical records in both groups (at the time of collection).

The following statistical tests were used for data analysis: Student's t-test, Mann-Whitney U test, Fisher's exact test and Chi-square test, logistic regression and ROC curve.

\section{Results}

We initially evaluated 963 external care forms from the Nephrology sector, selecting 293 (30.4\%) that belonged to patients with CC and ARF.

Dialytic post-renal AKIN 3 was found in 144 cases (49.4\%), with PCN being used as the clearance treatment in 99 (68.7\%). Among the patients submitted to PCN, we noted 61 cases $(61.7 \%)$ of recovery of kidney function, $25 \%$ resulting in in-hospital death and 13\% remaining on RRT. Only 45 (73.7\%) of patients submitted to PCN returned to outpatient monitoring and the remaining $26.3 \%$ never returned (Figure 1).

All 45 patients constituting the object of the research were initially cared for by the Nephrology team in dialytic emergency, and submitted to RRT and PCN, the urological procedure for renal/ureteral drainage and clearance, progressing with recovery of renal function and discharge from RRT.

The selected patients were evaluated on the basis of two types of outcomes: survival group (SG, $n=13)$ and death group (DG, n=32, Figure 1). The 45 patients were female, with an average age of $53.1 \pm 12.4$ years in SG and $46.2 \pm 14.6$ years in $D G(p=0.1409)$. 


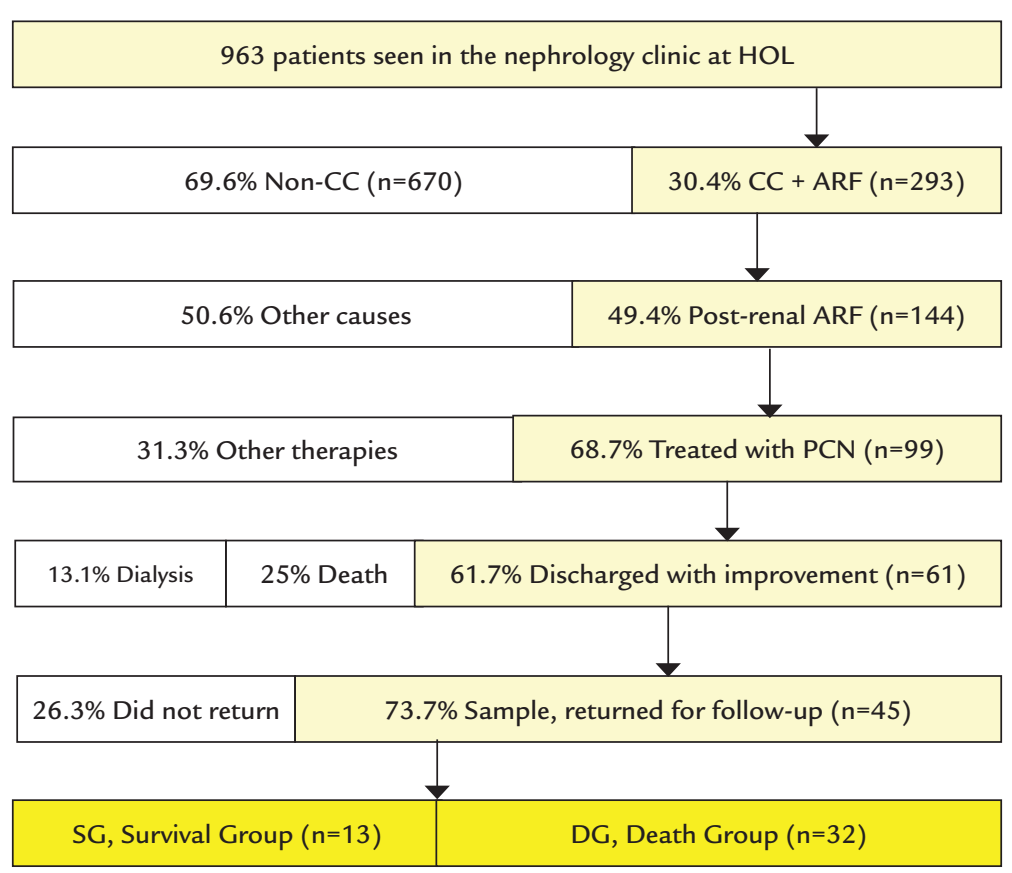

FIGURE 1 Selection of the 45 patients who participated in this study and the evolution of cases of urinary obstruction secondary to CC after

nephrostomy.

HOL: Hospital Ophir Loyola; CC: cervical cancer; PCN: percutaneous nephrostomy; ARF: acute renal failure.

In ARF assessment, the groups did not differ statistically in regard to serum levels of creatinine $(\mathrm{p}=0.5605)$ and urea $(\mathrm{p}=0.5256)$, dialysis time $(\mathrm{p}=0.6530)$ and nephrostomy time $(\mathrm{p}=0.5256)$. The initial laboratory characterization of ARF showed: $11.5 \mathrm{mg} / \mathrm{dL}$ of creatinine and $188.7 \mathrm{mg} / \mathrm{dL}$ of urea in SG and $10.1 \mathrm{mg} / \mathrm{dL}$ of creatinine and $165.4 \mathrm{mg} / \mathrm{dL}$ of urea in DG. The average dialysis time before the PCN was 22.6 days in SG and 25.3 days in DG. The average nephrostomy time was 6.6 months in SG and 7.6 months in DG (Table 1).

Comparing the results obtained in relation to the clinical characteristics of the neoplastic disease, there was no statistically significant difference $(p>0.05)$ between groups: current situation of tumor treatment in ARF care $(p=0.2912)$ and neoplastic clinical staging $(\mathrm{p}=0.9074)$. As to the type of treatment conducted, the groups showed no significant difference: radiation therapy $(\mathrm{p}=0.8605)$, chemotherapy $(p=0.2019)$ and surgery $(p=0.7422)$. Most patients were submitted to radiation therapy (SG 92.3\% and DG 93.8\%). In SG, chemotherapy was given to $30.8 \%$ and surgical treatment to $23.1 \%$ of patients. In DG, chemotherapy was given to $12.5 \%$ of patients and surgery to $18.8 \%$ (Table 2 ).

With respect to outpatient monitoring after hospital discharge, the comorbidities did not differ in a statistically significant manner between the groups ( $p>0.05)$. Note that hypertension (38.5\% in SG and $21.9 \%$ in DG, $\mathrm{p}=0.4422$ )
TABLE 1 Lab workup (blood dosages) and progression of the 45 patients with CC according to groups (SG = survival, and DG = death).

\begin{tabular}{lllll} 
Variable & & SG & DG & P value \\
\hline Creatinine in ARF & $(\mathrm{mg} / \mathrm{dL})$ & 11.5 & 10.1 & 0.5605 \\
\hline Baseline creatinine & & 1.86 & 1.94 & 0.4157 \\
\hline Final creatinine & & 1.75 & 1.94 & 0.7353 \\
\hline Urea in ARF & & 458.9 & 165.1 & 0.5256 \\
\hline Baseline urea & & 51.82 & 68.9 & 0.0971 \\
\hline Final urea & $(\mathrm{mL} / \mathrm{min})$ & 47.9 & 51.8 & 0.5817 \\
\hline $\begin{array}{l}\text { Baseline glomerular } \\
\text { filtration rate }\end{array}$ & & & & \\
\hline Final glomerular filtration & & 58 & 54.4 & 0.7926 \\
rate & & & & \\
\hline Nephrostomy & $(\mathrm{months})$ & 6.6 & 7.6 & 0.5256 \\
\hline Renal replacement therapy & $(\mathrm{days})$ & 22.6 & 25.3 & 0.6530 \\
\hline Baseline hemoglobin & $(\mathrm{g} / \mathrm{dL})$ & 9.27 & 8.47 & 0.0641 \\
\hline Final hemoglobin & & 9.99 & 8.25 & 0.0241 \\
\hline Baseline hematocrit & $(\%)$ & 26.94 & 24.99 & 0.2794 \\
\hline Final hematocrit & & 30.5 & 23.6 & 0.0065 \\
\hline Baseline sodium & $(\mathrm{mg} / \mathrm{dL})$ & 137.2 & 135.8 & 0.5278 \\
\hline Final sodium & & 137.7 & 133.5 & 0.087 \\
\hline Baseline potassium & $(\mathrm{mEq} / \mathrm{L})$ & 4.33 & 4.23 & 0.4398 \\
\hline Final potassium & & 4.56 & 4.18 & 0.3675 \\
\hline ARF: acute renal failure. & & & &
\end{tabular}


TABLE 2 Cervical cancer status, treatment and complications during PCN in the survival (SG) and deceased (DG) groups.

Variable

SG \% DG \% $\quad$ p-value

(13)

(32)

\begin{tabular}{llllll}
\hline Treatment status & & & & & 0.2912 \\
\hline Naïve & 0 & 0.0 & 2 & 6.3 &.. \\
\hline Under treatment & 5 & 38.5 & 16 & 50.0 &.. \\
\hline Recurrent with TP & 4 & 30.8 & 3 & 9.4 &.. \\
\hline Recurrent without TP & 4 & 30.8 & 10 & 31.3 &.. \\
\hline Staging & & & & & 0.9074 \\
\hline III & 5 & 38.5 & 10 & 31.3 &.. \\
\hline IV & 8 & 61.5 & 22 & 68.8 &.. \\
\hline
\end{tabular}

Treatment performed

\begin{tabular}{llllll}
\hline Radiotherapy & 12 & 92.3 & 30 & 93.8 & 0.8605 \\
\hline Chemotherapy & 4 & 30.8 & 4 & 12.5 & 0.2019 \\
\hline Surgery & 3 & 23.1 & 6 & 18.8 & 0.7422 \\
\hline
\end{tabular}

Complications

\begin{tabular}{llllll}
\hline Gross hematuria & 0 & 0.0 & 1 & 3.1 & 0.4857
\end{tabular}

\begin{tabular}{llllll}
\hline Accidental loss of the tube & 2 & 15.4 & 5 & 15.6 & 0.9998
\end{tabular}

\begin{tabular}{llllll}
\hline Urinary tract infection & 6 & 46.2 & 13 & 40.6 & 0.7512 \\
\hline Skin infection in the & 1 & 7.7 & 4 & 12.5 & 0.9877
\end{tabular}

tube's exit orifice

\begin{tabular}{llllll}
\hline Rash in the exit orifice & 0 & 0.0 & 1 & 3.1 & 0.4857 \\
\hline Pain at the tube's & 2 & 15.4 & 1 & 3.1 & 0.1961
\end{tabular}

insertion site

\begin{tabular}{llllll}
\hline Pyelonephritis & 0 & 0.0 & 0 & 0 &.. \\
\hline Sepsis & 0 & 0.0 & 1 & 3.1 & 0.4857 \\
\hline Hyperkalemia & 3 & 23.1 & 3 & 9.4 & 0.3342 \\
\hline Low blood pressure & 2 & 15.4 & 18 & 56.3 & $0.0197^{*}$ \\
\hline
\end{tabular}

TP: therapeutic possibility; hypothesis tests: Student's t and Mann-Whitney; *Fisher Exact Test.

and deep vein thrombosis (23.1\% in SG and $12.5 \%$ in DG, $\mathrm{p}=0.3942$ ) were the most frequent comorbidities.

In the evaluation of the laboratory characteristics during monitoring, baseline and final serum creatinine and urea in both groups were not statistically different; however, these findings characterized persistent renal dysfunction in both groups despite clearance of the urinary transit (Table 1).

Among laboratory variables that influenced progression to death, we can highlight the level of hemoglobin (Hb) which, in the final evaluation, differed statistically between SG and DG ( $p=0.0241$, Table 1$)$. The cutoff point of $8.7 \mathrm{~g} / \mathrm{dL}$ of $\mathrm{Hb}$ (ROC curve) indicates the value that best discriminates DG and SG, with $83.3 \%$ sensitivity, $56.7 \%$ specificity and $64.3 \%$ accuracy. The test's negative predictive value of $89.4 \%$ indicates high reliability in re- lation to prognosis (survival), when the patient presents $\mathrm{Hb} \geq 8.7 \mathrm{~g} / \mathrm{dL}$. On the other hand, the test's positive predictive value of $43.5 \%$ indicates high reliability in relation to a prognosis indicating death, when the patient presents $\mathrm{Hb}<8.7 \mathrm{~g} / \mathrm{dL}$.

The final Ht was also statistically different between the groups ( $\mathrm{p}=0.0065$, Table 1 ), in which case the Ht value that best discriminates patients depending on the outcome (death $v$ s. survival) resulted in a cutoff point of $27.0 \%$, which presented $76.9 \%$ sensitivity and $64.5 \%$ specificity.

Certain complications were noted in the groups during monitoring. Urinary tract infection showed a high frequency in both groups (46.2\% in SG and $40.6 \%$ in DG). Hyperkalemia was found in $23.1 \%$ of SG and $9.4 \%$ of DG in more than two samples collected during monitoring. DG presented a high frequency of low blood pressure (56.3\% in DG and $15.4 \%$ in SG). This finding differed in a statistically significant manner between the groups ( $p=0.0197$, Table 2$)$.

The evaluation of the glomerular filtration rate (GFR)MDRD at baseline did not statistically significantly differ $(p=0.5817)$ in the comparison between SG and DG. The same was also true for final GFR-MDRD ( $p=0.7926)$. There was no evidence of any relationship between the stage of CKD established by the MDRD equation and $\mathrm{Hb}$ levels or the evolution of the groups.

The multivariate logistic regression model identified a variable that was associated in a highly significant manner with death as an outcome, which was the occurrence of hypotension $(\mathrm{p}=0.0037)$. In this last analysis, the $\mathrm{Hb}$ $(p=0.4497)$ and $\mathrm{Ht}(\mathrm{p}=0.4748)$ variables were not statistically significant. The low blood pressure variable evaluated using Fisher's exact test ( $\mathrm{p}=0.0228)$, as well as by multivariate analysis, was really associated with the death of the patients as a risk factor, with an odds ratio of 7.8 (95CI between 1.3 and 55.8).

\section{Discussion}

Despite the existence of CC control programs in many centers, cervical cancer remains a disease with high prevalence, incidence and mortality. Every year half a million women are affected by this disease worldwide and 50 percent of them die due to CC. ${ }^{2}$

$\mathrm{CC}$ is the third neoplasm in Brazil that affects the female gender, and is more frequent in the Northern region, where it occupies first place among women in the state of Pará (24 cases/100,000). ${ }^{7}$

The incidence of ARF in cancer patients has been described in $27^{11}$ to $33 \%^{12}$ of the cases in different services. Knowing that ARF is an independent predictor of in-hos- 
pital death, ${ }^{13}$ the teams caring for patients with CC have united in an effort to change this outcome at the HOL.

Among the palliative treatments available for this group of patients with "malignant" ureteral obstruction due to local invasion, $\mathrm{PCN}$ has been used to restore urine flow in cases where anatomical deformities secondary to neoplastic disease and/or the clinical conditions of the patients do not enable other treatments.

We identified that $30.3 \%$ (293) of the cases of ARF attended at $\mathrm{HOL}$ were related to $\mathrm{CC}$, which shows that a significant portion of the ARF diagnoses are associated with CC at this service. One hundred and forty-four (49.4\%) of these cases presented urinary obstruction, which represents $15 \%$ of all ARF appointments at the hospital. This finding differs from that reported in the BIRMA Cohort Study (Belgium),${ }^{14}$ which noted a $6.5 \%$ incidence of gynecological cancer as a cause of this complication, perhaps reflecting a more effective primary prevention. In a Brazilian study,${ }^{15}$ the authors also found a low incidence of post-renal ARF, which was around 2 to $4 \%$.

PCN was conducted on 99 (68.7\%) of the 144 patients with urinary obstruction, while the remainder (45) did not present clinical conditions or refused treatment. After PCN, we noted the following developments: $61.7 \%$ were discharged with sufficient recovery of renal function to undergo outpatient monitoring without RRT, similar to the findings of the Romero group, which noted that $60.5 \%$ of patients undergoing urinary derivation due to "malignant" ureteral obstruction could return to their homes. ${ }^{3}$ A significant number of patients submitted to PCN did not regain renal function, remaining on RRT $(13 \%)$, which is in accordance with findings from a international multi-center study ${ }^{16}$ which found that $13.8 \%$ remain on dialysis, while $25 \%$ of patients progressed to death during hospitalization. This is a relatively low mortality rate when compared with the findings of Benoit and Depuyd ${ }^{17}$ who reported an in-hospital mortality rate of $85 \%$ among patients with cancer and ARF undergoing dialysis during hospitalization. In an international study that evaluated 1,738 patients with ARF (dialytic and nondialytic) admitted to an intensive care unit, ${ }^{16}$ the authors reported a $76.8 \%$ mortality rate in the sample corresponding to Brazilian patients $(\mathrm{n}=153)$. It is important to say that the evaluation of mortality described in this study was limited to simple frequency of death among the 99 patients who were subjected to RRT/PCN.

In relation to the recovery of renal function after clearance by PCN in our study, both groups benefited without distinction from the procedure, moving from serum levels of creatinine of 11.5 (SG) and $10.1 \mathrm{mg} / \mathrm{dL}$ (DG) to
1.86 (SG) and $1.94 \mathrm{mg} / \mathrm{dL}$ (DG). The same occurred with urea serum levels (Table 1 ).

Despite the benefits observed after installation of the PCN, in relation to the recovery of urinary flow and the possibility of leaving hospital, the mortality during monitoring after discharge among the 45 patients being accompanied was significantly greater than in-hospital mortality, given that $71 \%$ of patients progressed to death (32/45) during outpatient monitoring (Figure 1).

DG patients had a worse survival despite being younger, although this finding did not present statistical significance. This observation is in accordance with the findings of Nakagawa et al., who described lower survival rates in women with CC aged less than 50 years. ${ }^{18}$

There was a high frequency of urinary tract infection in both groups ( $46 \%$ in SG and $40.6 \%$ in DG). The treatment used the most was oral antibiotics at home. Three percent of the DG patients presented sepsis from urinary infection that might be related to the PCN. Serious complications such as abscesses, sepsis or hematoma associated with the PCN occur in less than $5 \%$ of cases. ${ }^{5}$ Hyperkalemia was diagnosed more than twice in $23 \%$ of the SG and 9.4\% of the DG during monitoring, without any tubular disorders having been identified. It is known that after urinary obstructive conditions, tubular disorders may occur that affect the reabsorption of electrolytes. These changes may occur either in isolation or in conjunction. ${ }^{5}$

Time of use of the PCN after discharge was 7.6 months in the DG and 6.6 months in the SG, which is consistent with the findings of Dagli and Ramchandani, who described survival and permanence of the tube for 6.8 months. ${ }^{19}$

Recent studies have indicated the benefits of using PCN in the treatment of urinary obstruction. Advanced malignant neoplasms have been the main indication for PCN, corresponding in different studies to $61,{ }^{19} 52^{20}$ and $58 \%{ }^{21}$

Analysis of the medical history revealed that high blood pressure (HBP) was the most frequent associated disease in both groups (38\% in SG and 21\% in DG), differing from the findings of the Ministry of Health, which describes 14\% HBP in the general population. ${ }^{22}$ Perhaps the impairment of renal function that remained chronic in the groups can be related to an increase in the frequency of HBP.

When we analyzed renal dysfunction through the average GFR, we noted that this did not differ between the groups, with $54 \mathrm{~mL} / \mathrm{min}$ in DG and $58 \mathrm{~mL} / \mathrm{min}$ in final laboratory evaluation. The reduction in renal function did not influence the evolution of the patients in the survival and deceased groups, and was also not associated with anemia (hemoglobin and hematocrit levels). We used the MDRD 
formula to measure the GFR as modified by Bastos, ${ }^{9}$ which only relies on age, sex and serum creatinine, given that during monitoring most patients did not present clinical conditions for the measurement of weight and had reduced muscle mass due to the advanced stage of the disease. Therefore, the GFR found may have been underestimated.

The presence of anemia in cancer patients is a frequent finding, leading to a significant impact on quality of life and survival time and may increase the risk of thrombotic events. These adverse effects are also observed in patients with chronic renal failure without neoplastic disease. ${ }^{23}$ Anemia in patients with neoplasm can be explained by several factors such as the increase in the cytokine interferon gamma, tumor necrosis factor alpha, interleukin (IL) IL1, IL6. ${ }^{24}$ As expected, anemia was a frequent finding in the groups studied, with an average final $\mathrm{Hb}$ (last collection) of $9.35 \mathrm{~g} / \mathrm{dL}$ in SG and $8.3 \mathrm{~g} / \mathrm{dL}$ in DG, which is a statistically significant difference $(\mathrm{p}=0.0241)$.

The ROC curve enabled us to identify that the levels of final $\mathrm{Hb}$ of $8.7 \mathrm{~g} / \mathrm{dL}(\mathrm{p}=0.0241)$ and final $\mathrm{Ht}$ of $27 \%$ $(p=0.0065)$ are the values that best distinguish the evolution of the patients studied, as values above these favor a greater survival rate while lower values favor progression to death. It should be made clear that treatment with human erythropoietin was not used in the groups.

A finding that drew a lot of attention in this study was the occurrence of low blood pressure, which was particularly more common in DG (56\% in DG vs. $15.4 \%$ in $\mathrm{SG}, \mathrm{p}=0.0197)$. It is worth mentioning that this was not associated with symptoms of sepsis, but it is possible that its occurrence, which is associated with a worse prognosis, results from a set of characteristics in these patients, such as anemia, malnutrition, remaining in a reclined position for a long time, dehydration (low circulating volume), frequent use of opioids, etc.

The multivariate analysis showed that among the clinical complications not related to the PCN itself, the presence of hypotension had an important influence on the "death" outcome ( $p=0.0037)$, but not the Hb $(p=0.4497)$ and $\mathrm{Ht}(\mathrm{p}=0.4748)$ variables. Low blood pressure unrelated with septic symptoms appeared as a risk factor for death, with an odds ratio of 7.8 (95CI between 1.3 and 55.8), which is in accordance with the findings of de Silva Júnior et al., who evaluated critically ill patients hospitalized at intensive care units, in which the presence of hypotension was associated with progression to death $(\mathrm{p}=0.001){ }^{25}$

\section{Conclusion}

By analyzing the clinical and laboratory progression of 45 women with CC treated with PCN due to obstruction of the urinary tract, we can conclude that PCN allowed the recovery of renal function and hospital discharge in $61.7 \%$ of the patients, dispensing with RRT. It is noteworthy that serum creatinine was greater than $10 \mathrm{mg} / \mathrm{dL}$ before the procedure and less than $2 \mathrm{mg} / \mathrm{dL}$ afterwards. The average time for remaining with the nephrostomy was 6.1 months in SG and 5.3 months in DG (Table 1). The most frequent complication related to the presence of the PCN tube was urinary tract infection. In relation to survival, among the various factors evaluated we can highlight the levels of $\mathrm{Hb} / \mathrm{Ht}$ and the occurrence of hypotension. Levels of $\mathrm{Hb}>8.7 \mathrm{~g} / \mathrm{dL}$ and $\mathrm{Ht}>27 \%$ were associated with greater survival among patients. A variation in the glomerular filtration rate, which was already low in all cases, was not associated with the levels of $\mathrm{Hb} / \mathrm{Ht}$ or progression to death during nephrological monitoring. The presence of hypotension during monitoring of patients with advanced CC was associated with progression to death and, in general, was not a result of sepsis.

\section{Resumo}

Câncer de colo uterino: complicações renais e sobrevida após nefrostomia percutânea

Introdução: a nefropatia obstrutiva é complicação frequente na evolução do câncer do colo uterino (CCU) avançado e a nefrostomia percutânea guiada por ultrassonografia (NFT) é uma técnica bem estabelecida para a rápida desobstrução ureteral.

Objetivo: esclarecer os fatores relacionados à evolução ou não para óbito e qualidade de vida das pacientes com CCU avançado com complicações obstrutivas urinárias agudas e que, após desobstrução pela NFT, recuperaram fluxo urinário e função renal.

Método: foi realizado estudo transversal analítico descritivo, que avaliou dois grupos de pacientes com CCU submetidas à NFT [óbito (GO) e sobrevida (GS)], em um hospital público, referência para doenças oncológicas da região Norte do país.

Resultados: a creatinina sérica média inicial era $>10 \mathrm{mg} /$ $\mathrm{dL}$ pré-NFT e tornou-se $<2 \mathrm{mg} / \mathrm{dL}$ após. Quanto à sobrevida, os pontos de corte de 8,7 g/dL de $\mathrm{Hb}$ e $27 \%$ de $\mathrm{Ht}$ melhor discriminaram a evolução dos grupos GO e GS $(p=0,0241$ e $p=0,0065)$. Hipotensão se associou significantemente $(\mathrm{p}=0,0037)$ com a evolução para óbito. Variações na taxa de filtração glomerular, que já era reduzida em todos os casos, não se associaram aos níveis de $\mathrm{Hb} /$ Ht ou à evolução para óbito durante seguimento nefrológico. 
Conclusão: a NFT permitiu a recuperação da função renal em $61,7 \%$ das pacientes com CCU, dispensando terapia de substituição renal. Níveis de $\mathrm{Hb}>8,7 \mathrm{~g} / \mathrm{dL}$ e $\mathrm{Ht}$ $>27 \%$ estiveram associados a maior sobrevida, e a hipotensão durante o seguimento associou-se com evolução para óbito.

Palavras-chave: obstrução ureteral, insuficiência renal crônica, nefrostomia percutânea, anemia, creatinina, sobrevida.

\section{References}

1. Carvalho R, Leite CG, Pereira DRS, Souza ER, Silva SSL. Carcinoma de células escamosas microinvasor - relato de caso. Rev Para Med. 2006; 20(3):65-9.

2. Federação Brasileira das Sociedades de Ginecologia e Obstetrícia (Febrasgo), Sociedade Brasileira de Cancerologia. Câncer do colo uterino: tratamento. Diretrizes Clínicas na Saúde Suplementar; 2011. [cited 2011 Jul 10]. Available from: http://www.projetodiretrizes.org.br/ans/diretrizes/cancer_do_colo_ uterino-tratamento.pdf.

3. Romero FR, Broglio M, Pires SR, Roca RF, Guibu IA, Perez MD. Indications for percutaneous nephrostomy in patients with obstructive uropathy due to malignant urogenital neoplasias. Int Braz J Urol. 2005; 31(2):117-24.

4. Ortiz V, Kiehl R. Obstrução do trato urinário causas e condutas. In: Schor N, Srougi M. Nefrologia urologia clínica. São Paulo: Sarvier, 1998. p.198-204.

5. Pereira BJ. Obstrução do trato urinário. In: Cruz J, Praxedes JN, Cruz HMM. Nefrologia. São Paulo: Sarvier, 2006. p.374-81.

6. Alves DS, Piatto JR, Carvalho JP, Souen J. Câncer de colo. In: Souen J, Carvelho JP, Pinotti JA (eds.). Oncologia genital feminina. 2.ed. São Paulo: Roca. 2001. p.257-75.

7. Instituto Nacional de Câncer. INCA. Controle do câncer de colo do útero. Conceito e magnitude; 2014. [cited 2014 Aug 3]. Available from: http:// www2.inca.gov.br/wps/wcm/connect/acoes_programas/site/home/nobrasil/ programa_nacional_controle_cancer_colo_utero/conceito_magnitude.

8. Kidney Disease: Improving Global Outcomes (KDIGO). Acute Kidney Injury Work Group. KDIGO Clinical Practice Guideline for Acute Kidney Injury. Kidney Int Suppl. 2012; 2(Suppl 1):1-138.

9. Bastos RMR, Bastos MG. Tabela de cálculo imediato da filtração glomerular J Bras Nefrol. 2005; 27(1):40-3.

10. Andrade JM, Yamaguchi NH, Oliveira AB, Perdicaris M, Pereira ST, Petitto $\mathrm{JV}$, et al. Rastreamento, diagnóstico e tratamento do carcinoma do colo do útero. Projeto Diretrizes: Federação e Obstetrícia. Sociedade Brasileira de Cancerologia; 2001. [cited 2011 Sep 14]. Available from: http://www. projetodiretrizes.org.br/projeto_diretrizes/030.pdf.

11. Dogan E, Izmirli M, Ceylan K, Erkoc R, Sayarlioglu H, Begenik H, et al. Incidence of renal insufficiency in cancer patients. Adv Ther. 2005; 22(4):357-62.

12. Launay-Vacher V, Izzedine H, Rey JB, Rixe O, Chapalain S, Nourdine S, et al. Incidence of renal insufficiency in cancer patients and evaluation of information available on the use anticancer drugs in renally impaired patients. Med Sci Monit. 2004; 10(5):209-12.

13. Pereira MB, Abulkader RCR. Impacto da insuficiência renal aguda na sobrevida a longo prazo. In: Cruz J, Cruz HMM, Kirsztajn GM, Barros RT Atualidades em nefrologia 11. São Paulo: Sarvier, 2010. p.195-200.

14. Janus N, Launay-VacherV, Byloos E, Machiels JP, Duck L, Kerger J, et al. Cancer and renal insufficiency results of the BIRMA study. Br J Cancer. 2010; 103(12):1815-21.

15. Costa JAC, Vieira Neto OM, Moysés Neto M. Insuficiência renal aguda. Simpósio: urgência e emergências nefrológicas. Medicina (Ribeirão Preto) 2003; 36(1):307-24

16. Uchino S, Kellum JA, Bellomo R, Doig GS, Morimatsu H, Morgera S, et al. Acute renal failure in critically ill patients: a multinational, multicentric study. JAMA. 2005; 294(7):813-8.

17. Benoit DD, Depuydt PO. Outcome in critically ill cancer patients: past and present. Rev Bras Ter Intensiva. 2008; 20(1):82-7.

18. Nakagawa JT, Espinosa MM, Barbieri M, Schirmer J. Carcinoma de colo do útero: taxa de sobrevida e fatores prognósticos em mulheres no Estado do Mato Grosso. Acta Paul Enferm. 2011; 24(5):631-7.

19. Dagli M, Ramchandani P. Percutaneuos nephrostomy: technical, aspects and indications. Semin Intervent Radiol. 2011; 28(4):424-37.

20. Karim R, Segupta S, Samanta S, Aich RK, Das U, Deb. P. Percutaneous nephrostomy by direct puncture technique: An observational study. Indian J Nephrol. 2010; 20(2):84-8.

21. Sood G, Sood A, Jindal A, Verma DK, Dhiman DS. Ultrasound guided percutaneous nephrostomy for obstructive uropathy in benign and malignant diseases. Int Braz J Urol. 2006; 32(3):281-6.

22. Brasil. Ministério da Saúde. Secretaria de Atenção a Saúde. Coordenação Nacional de hipertensão e diabetes. Hipertensão arterial e diabetes mellitus. [cited 2014 Aug 27]. Brasília: Minitério da Sáude, 2011. p.1-54. Available from: http://www.sbn.org.br/pdf/vigitel.pdf

23. Tonelli M, Hemmelgarn B, Reiman T, Manns B, Reaume MN, Lloyd A, et al. Benefits and harms of erythropoiesis-stimulating agents for anemia related to cancer: a meta-analysis. CMAJ. 2009; 180(11):E62-71.

24. Grotto HZW. Metabolismo do ferro: uma revisão sobre os principais mecanismos envolvidos em sua homeostase. Rev Bras Hematol Hemoter. 2008; 30(5):390-7.

25. Silva Júnior GB, Daher EF, Mota RMS, Menezes FA. Risk factors for death among critically ill patients with acute renal failure. São Paulo Med J. 2006; 124(5):257-63 